\title{
The Need for Tax Clarity and the Application of the Acte Clair Doctrine to Direct Taxes
}

Pasquale Pistone, EURYI-ESF Professor of European and International Tax Law at the Wirtschaftsuniversität Vienna and

European tax law has become a mature child: a legal system with its own principles, which faces new challenges, but requires a clear indication of the rights and obligations of taxpayers. Various factors seem to indicate that time has come for achieving such clarity.

According to the official statistics of the ECJ, taxation represented in 2006 the most numerous group of completed cases: 55 out of the total 426 that were completed, i.e. 12.5 per cent (or one-eighth) of the overall number of decisions and orders issued. Roughly one out of three tax cases involved direct taxes, thus showing that this field, some 100 judgments after the famous avoir fiscal decision, is no longer a peripheral area of European law left in the hands of the Member States, but one of the most important crossroads of European integration.

The mechanism of preliminary ruling procedures has shown some anomalies in this field. On the one hand, national courts of some Member States - such as Italy, Spain and Ireland - hardly refer cases in this field, whereas, on the other hand, waves of preliminary ruling procedures have reached the ECJ from other countries over the past few years, especially from the Netherlands, Germany (at present by far the main supplier of direct tax questions) and the United Kingdom.

Furthermore, the complexity of preliminary questions - in particular of those referred by the UK national courts in the framework of group litigation orders - has significantly increased the length and intricacy of the decisions of the ECJ, which scored the unprecedented record of 226 paragraphs in the Franked Investment Income decision.

The use of preliminary ruling procedures in the field of direct taxes is becoming more frequent in the new Member States. Hungary and, more recently (on 10 May 2007 on investment funds), Estonia have started to refer the first cases before the ECJ.

Although the number of preliminary ruling procedures filed in the field of direct taxes has slightly decreased in the first half of 2007, the Commission is currently launching a timely and appropriate campaign of infringement procedures (e.g. on dividends and pension funds) against the Member States, which often ignore decisions not involving them. Especially in countries whose national courts do not normally refer direct tax cases in the framework of preliminary ruling procedures, infringement procedures will gradually level out the rights of taxpayers with the ones enjoyed in other Member States and achieve a better compliance with European law. All such factors announce a further increase in the activity of the ECJ concerning direct taxes.

No one doubts that the ECJ will be able to face such challenge. However, reconciling new decisions with previous case law is becoming an increasingly difficult goal: a matter of which the ECJ is certainly aware.

Empirical signs indicate that the ECJ is making its best efforts to lead negative integration of direct taxes towards a sustainable growth, while keeping systematic consistency at the level of the Internal Market and perhaps even beyond it. Accordingly, the Court first opens a new judicial path and then gradually expands it. Decisions and orders refrain from making wide statements until the settlement of problems of compatibility with fundamental freedoms in a given tax area has been completed. It is a step-by-step approach, building up an a la carte jigsaw on the basis of what national courts from time to time require the ECJ to interpret. Despite being European law based on a nonbinding rule of precedent, there is little doubt that reconciling each statement with previous case law begets an increasing importance. Missing a precedent can thus jeopardize the whole consistency of the system and give rise to an overall legal uncertainty. Three examples give a clear idea of such problems.

First, the ECJ perhaps did not clearly identify the LOB issue in the first preliminary question of the ACT Group Litigation Order and instead equated it to MFN clauses. Had it taken into account the open skies case law, the conclusion should have been different and perhaps more closely seized the problems raised by LOB clauses.

Secondly, withholding taxes have been the subject of various decisions. In Scorpio the Court justified their levying on income paid to non-residents based on the absence of the Directive on assistance in collection of taxes without even mentioning the precedent of the Gerritse decision, which was instead confirmed by the later Denkavit France decision. The uncertainty becomes even greater if we consider that such Directive now applies to direct taxes and that from the Hoechst 
and Metallgesellschaft decision to Denkavit France the Court has generally recognized that the levying of withholding taxes raises a fairly evident problem of cash flow disadvantage against non-residents. Hopefully, the infringement procedures on dividends will solve the matter.

Thirdly, different definitions of abuse for European tax law purposes are possible according to whether one refers to the Halifax, Cadbury Schweppes, Thin Cap GLO and Kofoed decisions. And it is not just a matter of nuances. Yet in such four cases - all decided between 21 February 2006 and 5 July 2007 - the ECJ did mention the precedents, but drafted its decisions each time in a different way. According to the Halifax decision - a VAT case - abuse occurs when a transaction may not be justified on objective grounds other than the tax ones. Such definition frames abusive practices within the boundaries of tax avoidance, thus following the criteria used in many domestic legal systems. There seems to be little doubt that domestic anti-avoidance measures must from now on comply with the standards set by the Halifax decision, at least for VAT purposes.

By contrast, Cadbury Schweppes - a direct tax case on the compatibility of the UK CFC legislation with fundamental freedoms - takes abuse back to the traditional context of wholly artificial arrangements (first stated in the ICI decision). Reference to abusive practices in such decision (without a single mention of tax avoidance or evasion) overcomes the traditional linguistic inconsistencies (between tax avoidance and evasion). However, one may wonder whether the requirement of wholly artificial arrangements is by its own nature compatible with tax avoidance devices or, by contrast, is only met in cases of tax evasion, such as for instance letter-box companies, explicitly mentioned by the ECJ in the Cadbury Schweppes decision. Should such question be answered in the negative (and thus abuse be linked to tax evasion), then all national antiavoidance measures on cross-border situations could become unjustified restrictions on the exercise of fundamental freedoms: a matter that the Court may truly not have intended and that may have been avoided by taking into account the decision on the Thin Cap GLO case.

The Thin Cap GLO decision basically reproduces many of the issues that were already the subject of the Lankhorst-Hohorst decision, the exception being made for the third country issue, which the Court addressed in a fairly restrictive manner. Thin cap rules are by their nature anti-avoidance rules: this is undeniable. Even the reference to Cadbury Schweppes and to the formula of wholly artificial transactions (also contained in Lankhorst-Hohorst) could not turn a dog into a cat for tax purposes. Accordingly, one may wonder whether wholly artificial arrangements may be interpreted in a more flexible way, considering that - even beyond the case of letter-box companies - a tax-driven scheme may be wholly artificial when, despite its substance, objective grounds demonstrate that it was undertaken mainly for tax purposes. ${ }^{1}$

Unfortunately, clarity on abuse has not been achieved by the Kofoed decision, a direct tax case concerning the exchange of shares under the Merger Directive. Perhaps because of the Court's different composition (and reporting judge) in this case and of the different wording of Art. 11.1.a of the Merger Directive, which allows Member States to refuse to apply such Directive in the presence of schemes having tax evasion or tax avoidance as their principal objectives or as one of their principal objectives, the ECJ has given abuse yet another dimension. After acknowledging that such provision of the Merger Directive reflects the general Community principle that abuse of rights is prohibited, the Court ruled that taxpayers 'must not improperly or fraudulently take advantage of Community law', defining abusive practices as 'transactions carried out not in the context of normal commercial operations, but solely for the purpose of wrongfully obtaining advantages provided for by Community law' and making a final reference to Halifax and Cadbury Schweppes. Although expressions like 'improperly' and 'wrongfully ... take advantage of Community law' clearly give an idea of abusive practices, the more precise definition according to one single scheme seems a fairly hard task to achieve. Furthermore, reference to normal commercial operations could significantly broaden the scope of justifications based on anti-abuse grounds. After the Kofoed decision one could even conclude that not only may there be one notion of abuse for secondary law in the field of VAT and a different one for direct taxes, but also that the latter notion may differ according to whether we are dealing with fundamental freedoms (as in Cadbury Schweppes), or with a harmonized domain (as in Kofoed). Is this required by European law? In my opinion it is not.

Abuse of rights, or - perhaps more correctly - abuse of legal forms in the field of tax law, reflects a single and unitary general Community principle that does not deprive Member States of the right to apply their national anti-abuse measures even in the presence of secondary law. Accordingly, it should not matter whether or not a specific domain is regulated by a directive, since European law may never be used for improper purposes. Nevertheless, academics may only point out the need for clarity, which still remains a matter of exclusive competence of the single interpret of European law, i.e. the ECJ.

The need for clarity on abuse and the other issues becomes even more important if we consider that the evolution of European tax law is opening up a new phase of its direct tax case law: a phase of maturity, which may more heavily rely on national courts. The 
ECJ should limit its statements to what it is strictly indispensable for the interpretation of European law. From such perspective the Court should increase its trend to give precise definitions and make conceptual statements with a view to allowing national courts to deal with all remaining issues in the most appropriate way. We believe that a proper application of such mechanism facilitates the establishment of a tax acte clair, in the presence of which national courts would no longer be obliged to refer a case to the ECJ. ${ }^{2}$

Such situation would give rise to numerous advantages. First, tax technicalities would be left to national courts, which could interpret and apply them in the light of the criteria given by the ECJ. Secondly, taxpayers would obtain immediate protection, which in the presence of acte clair - could go so far as disapplying domestic law provisions that are incompatible with fundamental freedoms. Thirdly, it would avoid overburdening the ECJ with points of law that have already been object of previous statements, even though the questions at issue have been referred by the national court of other Member States and are not strictly identical. ${ }^{3}$ Fourthly, it would overcome problems of legal protection arising in countries whose national courts currently have not, or have very rarely, referred direct tax cases to the Court.

However, we must not forget that acte clair only exists when the national court is convinced that the matter is equally obvious to the courts of the other Member States and to the ECJ. ${ }^{4}$ Such would not, for instance, be the case regarding the possible implications of the Scorpio decision on withholding taxes after the Directive 76/308/EEC has been extended to direct taxes. By contrast, a good example of the application of tax acte clair by a national court is the decision of 10 May 2007 by the Finnish Supreme Administrative Court, which - based on the right to national treatment stated by the ECJ in the Saint-Gobain decision - obliged Finland to give a Luxembourg company with a Finnish PE receiving royalties from China tax sparing at the same conditions that would apply under the Finland-China Tax Treaty.

\section{Notes}

2 A conference has been organized on 17-18 September 2007 at the University of Lisbon for the purpose of defining and building up the direct tax acte clair.

3 ECJ, 6 October 1982, case 283/81, Cilfit and Lanificio di Gavardo, para. 14.

4 Ibid., para. 16. 